\title{
Stimmungen no Fausto de Aleksandr Sokurov
}

\author{
[Stimmungen in the Faust by Aleksandr Sokurov] \\ http://dx.doi.org/10.1590/1982-883718264671
}

\begin{abstract}
This work aims at analyzing the construction of the Stimmungen (atmospheres) in the free-adaptation of the Goethe's Faust made in 2011 by the Russian director Aleksandr Sokurov. Within this perspective, we seek to demonstrate in particular how the dialogue between Sokurov and Goethe does not happen only in realm of the plot, but also in the peculiar way in which both use the technique as a way of modulating the spectators' affections.
\end{abstract}

Keywords: Faust; Stimmung; Sokurov; Goethe.

Resumo: Este trabalho tem como objetivo analisar a construção das Stimmungen (atmosferas) na livre-adaptação do Fausto de Goethe realizada, em 2011, pelo diretor russo Aleksandr Sokurov. Dentro dessa perspectiva, buscaremos demonstrar, particularmente, como o diálogo entre Sokurov e Goethe não se dá somente no domínio do enredo, mas também no modo peculiar como ambos se utilizam da técnica como forma de modulação dos afetos dos espectadores.

Palavras-chave: Fausto; Stimmung; Sokurov; Goethe.

\section{Introdução}

Johann Wolfgang von Goethe foi um homem que, assim como o Dr. Fausto, submeteu sua vida às consequências de uma aliança. Não exatamente com Mefistófeles, como o fez o célebre protagonista de sua tragédia, mas com a ciência, o que particularmente influiu sobre as imbricações entre técnica e estética em sua obra. Dentro dessa perspectiva, sua apreciação das artes plásticas perpassa, inequivocamente, as reflexões sobre o efeito sensível-moral da cor expostas em Doutrina das cores (Farbenlehre, 1810); assim como, em uma passagem de Os sofrimentos do jovem Werther (Die Leiden des Jungen Werthers, 1774), o escritor alemão alude às propriedades óticas de um

\footnotetext{
${ }^{1}$ Universidade Federal Fluminense (UFF), Rua Marcos Waldemar de Freitas s/n, Campus do Gragoatá, 24210-201, Niterói/ RJ, Brasil. Email: Alekzmartony@ hotmail.com
} 
Martoni, A. - Stimmungen no Fausto de Sokurov

dispositivo técnico muito popular em seu tempo - a lanterna mágica - para construir uma cena de um onirismo, digamos, pré-cinematográfico:

Wilhelm, o que seria o mundo, para o nosso coração, sem amor! Uma lanterna mágica sem luz! É só trazeres a lamparina, e logo imagens multicoloridas se projetam na parede branca! E, se estas imagens não passarem de fantasmas efêmeros, ainda assim sentimonos felizes postando-nos diante delas, como crianças, encantados ao contemplar essas aparições maravilhosas (GOETHE 2000: 48).

A presença destes fenômenos óticos espetaculares, na obra de Goethe, pode ser pensada como um modo singular de o escritor construir, no domínio estético, um tipo de experiência sensível que, habitualmente, indicamos com a palavra atmosfera. Em Fausto, versos como "Wie von magischer laterne [Como em mágica lanterna]" (GOETHE 2004: 137), “abscheuliche Gespenster [horroríferos fantasmas]” (2004: 355) e “dunstiger Nebel [denso vapor]" (2004: 255), parecem ter sido elaborados, conforme hipótese levantada por Albrecht ScHÖNE (2005), tendo em vista as técnicas e fenômenos visuais que o escritor alemão desejava que fossem empregados na montagem da peça. É neste sentido que o desafio que se impõe a Aleksandr Sokurov, na construção da miseen-scène do seu Fausto, realizado em 2011, consiste em compreender que tipo de atmosfera irrompe na obra de Goethe a partir das afinidades eletivas que ela revela entre técnica e estética.

Em uma carta enviada em 1828 ao diretor Ernst Klingermann, Goethe expunha a necessidade de algumas cenas da peça, como a da aparição do Erdgeist (Espírito da Terra), apresentarem uma determinada potência para assustar, "erschrecken" (MAHL 1998: 20), os espectadores; e é justamente o desejo de construir esse tipo de atmosfera que parece ter orientado a versão de Aleksandr Sokurov. Uma visada sobre a recepção crítica do filme do realizador russo não nos parece deixar dúvidas quanto à natureza inquietante de seu filme: A. O. Scott, no New York Times, declarou ter sido acometido por um sentimento claustrofóbico, "claustrophobic feeling” (SCOTT 2013); Steven Rose, no The Guardian, definiu-o como uma experiência alucinante, "allucinatory" (RoSE 2011); e Cyril Béghin, nos Caihers du Cinéma, caracterizou-o como uma obra “[...] découplées en métaphores pleines et physiques, les sensations que l'on n'a cesse d'éprouver pendent deux heures étourdissantes"”2 (BÉGHIN 2012).

\footnotetext{
2 “dissociado em metáforas plenas e físicas, as sensações não param de nos afetar ao longo de duas horas atordoantes" (tradução minha).
} 
Martoni, A. - Stimmungen no Fausto de Sokurov

É dentro dessa perspectiva que nossa questão fundamental, neste trabalho, consistirá em compreender, efetivamente, o papel desempenhado pela técnica no processo de construção das atmosferas no Fausto de Aleksandr Sokurov. Neste sentido, buscaremos desenvolver nossa investigação em três etapas: começaremos refletindo sobre os pontos de convergência entre a obra de Sokurov e a de Goethe, que lhe serve de base, buscando pensar sobre os sentidos político e estético de Fausto hoje, dentro da cultura contemporânea. Neste ponto, emergirá a questão da atmosfera enquanto um fenômeno que, por se situar em um domínio para além do campo hermenêutico, demanda novos instrumentos operatórios. Em um segundo momento, buscaremos refletir sobre como a singularidade de sentido apresentada pelo vocábulo alemão Stimmung se oferece de modo produtivo para pensarmos, justamente, sobre essa forma de experiência sensível que designamos com termo atmosfera. Em nossa última etapa, nos dedicaremos à análise de alguns fenômenos óticos do filme de Aleksandr Sokurov como modo de compreensão de como a técnica é empregada na construção das Stimmungen de seu filme. Neste ponto, ficará evidenciado como o diálogo entre Sokurov e Goethe não se dá somente no domínio do enredo, mas também no modo peculiar como ambos se utilizam da técnica como forma de modulação dos afetos dos espectadores.

\section{De Sokurov a Goethe}

O Fausto de Aleksandr Sokurov se apresenta como uma livre-adaptação da tragédia de Johann Wolfgang von Goethe. Neste sentido, o realizador russo, juntamente com os roteiristas Marina Koreneva e Yuri Arabov, se aproveita da significativa plasticidade da tragédia alemã. Como se sabe, formalmente, o Fausto de Goethe é uma obra bastante heterogênea, com grande variedade de gêneros, formas e ritmos. Em seus 12.111 versos, é possível encontrar de canções populares a digressões filosóficas, de feeries mitológicas a dramas psicológicos e sociais. Desse modo, o realizador russo não só se beneficia com a riqueza e variedade do texto de Goethe, como também busca torcê-lo e plasmá-lo à sua maneira: no Fausto de Sokurov, Mefistófeles não é mais a figura de maquiagem pesada e de forte gestualidade não-naturalista, como habitualmente se via nas encenações da peça, mas nos é apresentada transfigurada na forma de um agiota, vestido rigorosamente à moda burguesa do século XIX; as viagens por diferentes zonas espaço-temporais, através das quais Fausto tinha visões alucinantes - como o rito 
Martoni, A. - Stimmungen no Fausto de Sokurov

orgiástico da "Noite de Valpúrgia" (Walpurgisnacht) -, se transforma em um percurso terrestre a partir do qual os personagens entram e saem naturalmente dos ambientes, observando e interagindo com as vicissitudes do mundo dos vivos; já as aparições e desaparições de Mefistófeles ocorrem sem nenhum tipo de espetacularização, como as brumas e trovões que marcam, por exemplo, a célebre adaptação realizada pelo cineasta alemão F. W. Murnau em 1926. É desse modo que a plasticidade do mito de Fausto se oferece a Sokurov como modo de incorporação das tensões próprias à cultura moderna, como o diretor revela em uma entrevista a Jeremi Szaniawski: "I wanted to turn Faust into a man of the early nineteenth century and to put all these burdens on his shoulders."3 (SZANIAWSKI 2014: 303).

Fausto, como nos lembra Walter Benjamin, é um homem de "ambição selvagem e inquieta" (BENJAMIN 2009: 172), e é exatamente dentro dessa perspectiva que Sokurov o lê - gesto que o insere dentro de uma clave interpretativa bem contemporânea, a partir da qual o protagonista da tragédia é visto tanto como um dos "mitos do individualismo moderno" (WATT 2007), como postula Ian Watt; quanto como uma metáfora da gênese do capitalismo financeiro, como aponta Marshall Berman (BERMAN 1997). O que o realizador russo busca fazer, efetivamente, em seu Fausto, é apontar como os modos de exercício do poder estão intimamente ligados à esfera de uma ambição individual. Não é por acaso que o seu Fausto é o último filme de uma série que ele denomina como "tetralogia do poder", um conjunto de quatro obras através das quais busca refletir sobre as consequências dos modos como quatro personagens históricos exercem o poder ${ }^{4}$ : Hitler, em Moloch (1999); Lênin, em Taurus (2001); Hiroíto, em $O$ Sol (2005) e, Fausto, no filme homônimo de 2011.

Se, por um lado, o filme de Sokurov dialoga com essa tradição contemporânea de pensar o mito de Fausto na clave das consequências do desenvolvimento do sistema de valores da sociedade burguesa, por outro, flerta com a tradição da ficção fantástica moderna, na qual o extraordinário irrompe sutilmente do mundo natural. Nesse sentido, ainda que Mefistófeles apareça vestido de modo condizente com a realidade do seu

\footnotetext{
3 "Eu queria transformar Fausto em um homem do início do século XIX e colocar todo esse fardo sobre os seus ombros" (tradução minha).

${ }^{4}$ Em entrevista a Jeremi Szaniawski, Sokurov afirma que: "The fundamental question, indispensable and central to the tetralogy is in my view the following: At the what price does a man choose to sell - or on the contrary, not to sell - his soul? That's what these films talk about, most of all, and the consequences that ensue of course". "A questão fundamental, indispensável e central para a tetralogia, no meu ponto de vista, é a seguinte: A que preço o homem escolhe vender - ao, ao contrário, não vender - sua alma? É sobre isso que o filme fala, em sua maior parte, e as consequências que decorrem dessa escolha, claro" (tradução minha). SZANIAWSKI (2014: 299).
} 
tempo, portando cartola e casaca à moda burguesa, ao despir-se para se banhar, revela possuir um corpo disforme, destituído de órgão sexual e a sutil presença de um pequeno rabo. Em outra passagem do filme, para se livrar de um conflito numa taverna, Mefistófeles fura, com um espeto, uma parede, de onde, subitamente, começa a jorrar vinho. Em outra cena, Margarida é interpelada por Wagner, assistente de Fausto, que lhe apresenta um homúnculo, embrião produzido a partir de um processo de nigromancia. Digamos que, à maneira kafkiana, o sobrenatural não se anuncia de forma espetacular, mas irrompe sutilmente do clima de aparente normalidade, destituído de quaisquer explicações. Desse modo, constrói-se uma realidade inquietante, na medida em que ela suscita momentos de incerteza ao exame intelectual.

Não obstante este papel desempenhado pelas relações de sentido estabelecidas no plano do enredo, há também, no domínio da mise-en-scène, um conjunto de fenômenos óticos que diuturnamente nos inquietam ao longo do filme; fenômenos que, por se situarem fora do plano hermenêutico, demandam a busca de novos instrumentos operatórios para que sejam compreendidos. São eles que, de fato, cumprem um papel fundamental na modulação dos nossos afetos, na construção de um tipo de experiência sensível que denominamos como "atmosfera". Mas de que forma, efetivamente, poderíamos submeter a um processo analítico aquilo que se situa nessas forças de encontro entre a imagem e a nossa percepção?

\section{Atmosferas no cinema}

De acordo com Leo Spitzer (1968), a palavra Stimmung foi lexicologicamente constituída ao longo do século XVIII. Sua origem estaria ligada, fundamentalmente, a fenômenos do campo semântico da música, como a expressão gestimmt sein, que alude à condição de "estar afinado"; ao verbo stimmem, que indica a ação de afinar um instrumento; e ao substantivo Stimme (voz).

Paradoxalmente, aquilo de mais produtivo que essa palavra pode oferecer para os estudos de estética consiste em uma singularidade de sentido que dificulta sua tradução. Leo Spitzer começa o seu estudo sobre a história semântica da palavra 
Martoni, A. - Stimmungen no Fausto de Sokurov

Stimmung afirmando: "É fato que um termo como o alemão Stimmung é intraduzível"5 (SPITZER 2008: 15). Contudo, logo em seguida, o teórico ressalta que isso não significa que frases como "die Stimmung in diesem Bilde" (2008: 15) não poderiam ser traduzidas como "l'atmosphère de ce tableau [a atmosfera deste quadro]" (2008: 15). O problema é que nenhuma tradução consegue abarcar o potencial que o sentido dessa palavra tem para se referir, simultaneamente, àquilo que é observado, por exemplo, uma paisagem; e o modo como essa paisagem é sentida enquanto é observada. Como Spitzer destaca:

O que falta às principais línguas europeias é um termo que possa expressar a unidade de sentimentos experimentada pelo homem diante de seu entorno (uma paisagem, natureza, outro ser humano), e compreenda e una o objetivo (fático) e o subjetivo (psicológico) em uma unidade harmoniosa (2008: 15).

Em outras palavras, como observa o germanista americano David WELLBERY (2003), se nós a traduzimos como "atmosfera", nos concentramos na dimensão objetiva; se a traduzimos como "humor" ou "disposição", atentamos à dimensão psicológica. Para um alemão, voltando às reflexões de Spitzer, é possível dizer algo como "minha Stimmung" ou "a Stimmung de uma paisagem"; ao passo que, em português, soaria estranho dizer "minha atmosfera" ou "o humor dessa paisagem" (2008: 15). Portanto, a riqueza semântica dessa palavra está no seu potencial de expressar, concomitantemente, aquilo que me afeta e o modo como eu me vejo sendo afetado, apagando, desse modo, a dicotomia epistemológica tradicional sujeito/objeto, tendo em vista que, ainda para SPITZER, "para um alemão, Stimmung está fundida com a paisagem, a qual, por sua vez, está animada pelo sentimento do homem: é uma unidade indissolúvel em que homem e natureza estão integrados" (2008: 15).

Ainda que apresente uma singularidade semântica que a torna intraduzível, Hans Ulrich GUMBRECHT aposta na possibilidade de aproximação do sentido de Stimmung às acepções metafóricas das palavras atmosfera, clima e ambiência. No livro Atmosfera, ambiência, Stimmung (2014), o teórico da literatura e da cultura propõe o desenvolvimento de um modo de leitura voltado àquilo que ele entende como "um potencial oculto da literatura" (GUMBRECHT 2014: 14); isto é, uma capacidade que a palavra, na sua própria materialidade, teria de despertar certas modulações afetivas no leitor. Nesse sentido, conclui GUMBRECHT, “'Ler com a atenção voltada ao Stimmung’

\footnotetext{
${ }^{5}$ Todas as traduções do livro de Leo Spitzer foram por mim realizadas a partir da sua versão em espanhol: SPITZER (2008).
} 
Martoni, A. - Stimmungen no Fausto de Sokurov

sempre significa prestar atenção à dimensão textual das formas que nos envolvem, que envolvem nossos corpos, enquanto realidade física" (2014: 14). É justamente nessa perspectiva que propomos uma aproximação entre os vocábulos atmosfera e Stimmung. Ao produzir fenômenos óticos e acústicos que entram em contato substancial com os nossos corpos, o cinema nos envolve materialmente em uma determinada atmosfera, Stimmung, influindo, desse modo, sobre as nossas modulações afetivas.

No cinema, a palavra Stimmung foi largamente empregada pelos fotógrafos do expressionismo, como Carl Mayer, que buscaram levar às salas de projeção uma atmosfera própria ao teatro intimista alemão - Kammerspiel -, obtida através do modo como a luz e as sombras caíam sobre o cenário, os atores e os objetos de modo a sugerir ambiências, dotá-los de força expressiva. Neste intuito, os roteiros vinham com indicações muito precisas que visavam a sugerir que tipo de atmosfera deveria predominar em um determinado cenário, como no de A noite de São Silvestre (Sylvester, 1923), de Lupu-Pick, em que é possível encontrar expressões como "fumaça espessa", "luz vacilante", "Cabaré. Eflúvios densos. Fumaça. Luz baça" (EISNER 2002: 135). Para Lotte Eisner, esses efeitos plásticos são os principais responsáveis pela modulação dos afetos do espectador, uma vez que "a Stimmung flutua em torno tanto dos objetos quanto das personagens: é uma consonância metafísica, uma harmonia mística e singular em meio ao caos das coisas, uma espécie de nostalgia dolorosa [...]" (EISNER 2002: 135). É importante, ainda, acrescentar que o desejo de criação de determinadas conformações atmosféricas em uma imagem já fazia parte de uma tradição da cultura visual alemã chamada Stimmungsbild. Como nos lembra Susan BucK-Morss, a Stimmungsbild era "uma 'pintura da atmosfera ambiental', um gênero que estava em voga na época e visava a retratar um 'clima' ou uma atmosfera, mais que um sujeito" (BUCK-MoRSS 2012: 174). É dentro dessa perspectiva que, no âmbito deste trabalho, pensar a construção de Stimmungen no Fausto de Aleksandr Sokurov significa refletir sobre como a técnica cria uma atmosfera ambiental, um modo de experiência sensível em que forças de encontro entre a dimensão material da imagem e o domínio perceptivo-cognitivo suscitam afetos na ordem daquilo que os críticos apontam como claustrofóbico, alucinante e atordoante. 


\title{
4 Stimmungen no Fausto de Aleksandr Sokurov
}

Ao evocar a presença do Erdgeist (Espírito da Terra), na cena de abertura da tragédia de Goethe - Nacht (Noite) -, Fausto se vê, subitamente, envolto por uma mudança significativa nas condições atmosféricas:

\author{
Es wölkt sich über mir - \\ Der Mond verbirgt sein Licht - \\ Die Lampe schwindet! \\ Es dampft - Es zucken rote Strahlen \\ Mir um das Haupt - es weht \\ Ein Schauer vom Gewölb' herab \\ Und faßt mich an!
}

Nubla-se o espaço sobre mim -

Oculta a lua o seu clarão -

A luz se esvai!

Sobe um vapor! - Coriscam raios rubros

À minha volta - Um sopro frio

Desce da abóboda e me invade! (GOETHE 2004: 69)

Na medida em que se tratava de um texto escrito para a encenação, Fausto lançava um desafio na ordem de sua mise-en-scène: como criar um espetáculo cujos fenômenos óticos sejam verdadeiramente inquietantes para os espectadores? Esta foi uma questão central para Goethe, que, na ocasião da primeira montagem integral do Primeiro Fausto, envia uma carta ao diretor Ernst August Friedrich Klingemann recomendandolhe que alguma tecnologia fosse empregada para tornar a aparição do Erdgeist uma experiência realmente assustadora:

Diese Darstellung des Erdgeites stimmt im Ganzen mit meiner Absicht überein. Dass er durch's Fenster hereinsieht, ist gespensterhaft genug. Rembrandt hat diesen Gedanken auf einem radirten Blatte sehr schön benutzt ${ }^{6}$ (MAHL 1998: 20).

A solução apresentada por Goethe para tornar Fausto um espetáculo verdadeiramente perturbador transcende o plano do enredo e do significado das palavras e vislumbra um tratamento plástico da mise-en-scène que proporcione ao público uma experiência em

\footnotetext{
6 "Esta representação do Erdgeist está, em geral, de acordo com a minha intenção. O modo como ele olha pela janela é medonho o suficiente. Rembrandt usou essa ideia em uma agradável gravura" (tradução minha).
} 
que o inquietante irrompe na contemplação de fenômenos óticos que desafiam a nossa percepção habitual das coisas. É exatamente esse o desafio que se impõe a Aleksandr Sokurov em sua adaptação da tragédia de Goethe: como produzir, tecnicamente, um espetáculo em que as atmosferas mantenham a natureza inquietante de Fausto?

Uma vez que as Stimmungen estão, como mostramos, estritamente vinculadas ao modo como os fenômenos relativos à materialidade da linguagem influem sobre a nossa dimensão afetiva, o trabalho de adaptação realizado por Sokurov poderia ser pensado como uma espécie de tradução de ambiências; em outras palavras, em um processo através do qual o realizador russo torce a matéria expressiva para gerar sentidos em direção à claustrofobia, à alucinação e ao atordoamento, para nos reportarmos, uma vez mais, às expressões empregadas na recepção do filme. Dentro dessa perspectiva, iremos nos concentrar, particularmente, nesta análise de Fausto, nos três conjuntos de fenômenos imagéticos que consideramos fundamentais para a compreensão de suas Stimmungen: ponto de vista e movimento; luz e cor; e deformação.

\subsection{Ponto de vista e movimento}

Qual é o olhar de Fausto sobre o mundo? Na segunda cena do filme de Sokurov, vemos o médico realizando, junto com seu assistente, Wagner, a dissecação de um cadáver em busca de uma glândula onde supostamente se alojaria a alma do ser humano, em uma espécie de busca pela glândula pineal, ponto em que Descartes especulava se dar a união substancial entre corpo e alma (DESCARTES 2011). A maneira como o olhar do médico perscruta o corpo, tencionando suas aberturas e arrancando suas vísceras já é indicativo do modo como Fausto vê o mundo: um lugar de encenação da ansiedade e angústia do homem com a constatação das limitações impostas pela própria pequenez da condição humana. Desse modo, o mundo, para Fausto, é um lugar cujo saber está hermeticamente fechado. O mundo é, nessa perspectiva, claustrofóbico.

Essa tensão entre o homem e o mundo, do ponto de vista existencial, se projeta para o próprio plano da mise-en-scène. Ao longo do filme, os percursos realizados pelo médico são marcados por uma luta corporal entre o sujeito e as limitações dos espaços por onde ele circula, que lhe impõem necessidades diversas: de se curvar em virtude do pé-direito baixo de sua casa; de se desviar dos objetos amontoados e dependurados do 
Martoni, A. - Stimmungen no Fausto de Sokurov

escritório de Mauricius Müller; de tentar furar o bloqueio que uma procissão oferece ao seu trajeto. O mundo é, lembremos, claustrofóbico para Fausto. Contudo, não é só o olhar do médico que está sob a tutela da claustrofobia; a maneira como Aleksandr Sokurov configura os modos de o espectador ver esse espaço nos impõe um olhar cerrado sobre o mundo. O mundo é claustrofóbico para Fausto e também o é para o espectador.

O olhar que o espectador deposita no filme, nos lembra Arlindo Machado, "é subsidiário de um outro olhar, aquele que determina o ângulo, a distância e a duração segundo os quais o motivo é dado à visão" (MACHADO 2007: 10). Desse modo, somos testemunhas de um olhar que espreita, esquadrinha o mundo do Dr. Fausto. Mas de que forma a natureza plástica, material desse olhar influi sobre as nossas disposições afetivas; torna o mundo, para o espectador, tão claustrofóbico quanto o de Fausto?

Para um espectador, hoje, o estranhamento com o filme de Sokurov já tem início na própria amplitude do olhar que nos é oferecida pela sua projeção, que ocupa um espaço bem menor da tela, em relação ao que estamos acostumados no cinema atual. Esse espaço exíguo de visão é tributário da adoção, por Sokurov, do uso da janela ${ }^{7}$ 1.37:1, formato comum no período do cinema clássico norte-americano, mas que caiu em desuso e perdeu espaço para outros padrões, sobretudo o 1.85:1, atualmente standard nos estúdios de Hollywood. A adoção do formato 1.37:1 diminui o comprimento da imagem, reduzindo sua horizontalidade. Portanto, a escolha da janela a ser adotada acaba influindo sobre as configurações do que vemos e como vemos, o que permite, ao realizador, determinar o que se deseja apontar como fundamental em um quadro, como é possível notar nos três planos recortados por diferentes tipos de janelas nos fotogramas do filme Notre Musique (2004), de Jean-Luc Godard, a partir dos quais percebemos a diferença entre as janelas 1.37:1, 1.66:1 e 1.85:1, respectivamente, e suas implicações nos modos de ver o rosto da atriz Sarah Adler:

\footnotetext{
${ }^{7}$ De acordo com David BoRDwELL, framing (janela, em português), "is not simply a neutral border; it produces a certain vantage point onto the material within the image. In cinema the frame is important because it actively defines the image for us". "não é simplesmente uma borda neutra; ela produz um certo ponto-de-vista privilegiado sobre a imagem. No cinema, a janela é importante porque ela é responsável por definir a imagem para nós" (tradução minha). BORDWELL/ THOMPSON (2009: 201).
} 
Martoni, A. - Stimmungen no Fausto de Sokurov

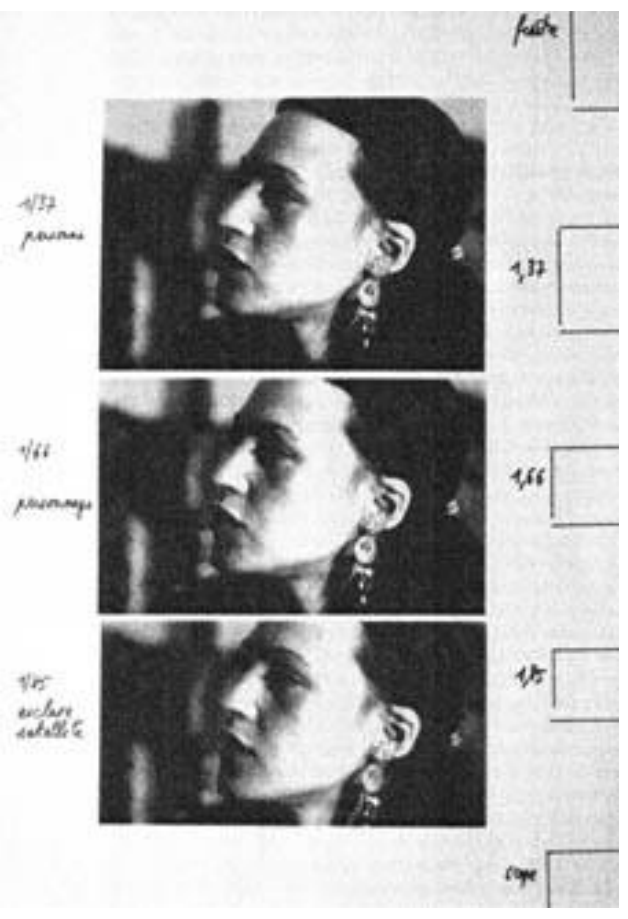

Figura 1: O mesmo fotograma do filme Notre Musique recortado em três tipos de janelas ${ }^{8}$.

No Fausto de Sokurov, essa visão exígua do espaço determina uma espécie de concentração de forças sobre a imagem; isto é, em vez de essas linhas de força se distribuírem centrifugamente do objeto focal para o espaço circundante, fazendo o nosso olhar buscar o que está no entorno, ela se concentra, centripetamente, no objeto focal, nos fazendo atentar aos seus volumes, texturas e luminosidades, tal como ocorre, por exemplo, nos planos fechados no rosto de Margarida, como nos mostra a imagem a seguir:

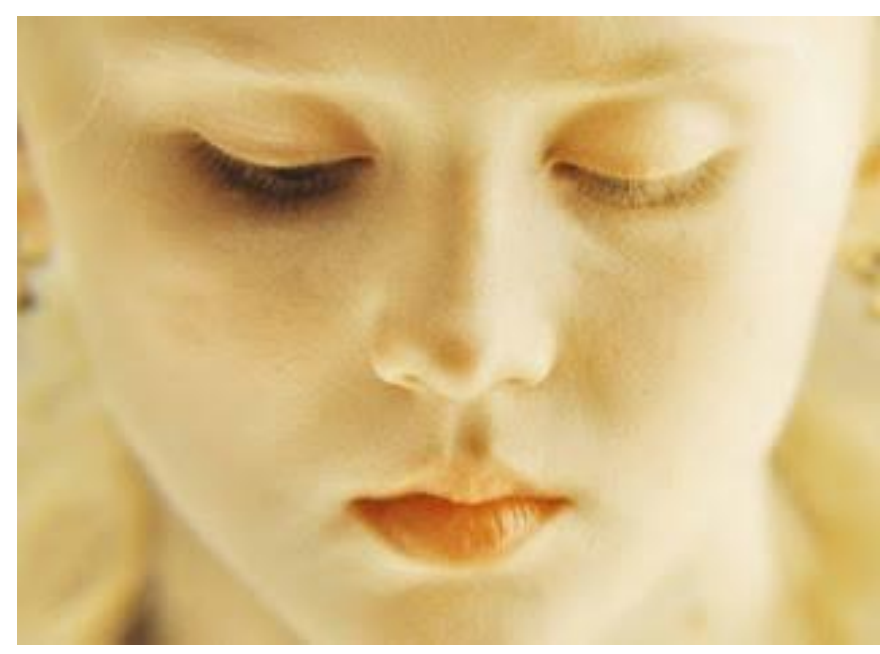

Figura 2: Fotograma do filme Fausto apresenta o rosto de Margarida em close-up ${ }^{9}$.

8 Fonte: http://www.davidbordwell.net/blog/2007/12/14/godard-comes-in-many-shapes-and-sizes/. Acesso em: 7 mar. 2014. 
Martoni, A. - Stimmungen no Fausto de Sokurov

Neste plano fechado, a luz e a cor que banham o rosto da atriz russa Isolda Dychauk parecem preencher todo o quadro, para além dos limites estabelecidos pelos contornos do próprio rosto. Poderíamos nos apropriar, aqui, de uma feliz expressão concebida por Jean Epstein para se referir aos efeitos provocados pelos planos em close up dos filmes de Marcel L’Herbier: o rosto de Margarida “é luz pura solidificada num estágio próximo da ternura" (EPSTEIN 1983: 280). Portanto, a adoção da janela 1.37:1, diminuindo a amplitude horizontal da imagem, provoca uma fixação de toda a energia do nosso olhar no centro da imagem, onde vemos o rosto, cabendo às zonas periféricas uma espécie de dissolução dessa face, algo que poderíamos aproximar da noção deleuziana de traços de rosticidade, que, segundo o filósofo francês, seriam "traços dispersos feitos na massa, por linhas fragmentárias e quebradas [...] e que engendram uma matéria mais ou menos rebelde ao contorno" (DELEUZE 1983: 138). Desse modo, as conformações visuais desse plano parecem conferir à imagem uma dimensão onírica, como uma experiência de natureza alucinatória.

O cerceamento da amplitude do olhar realizado pela janela 1.37 acaba, também, por potencializar as limitações que já nos são impostas pela própria mise-en-scène. Na medida em que Fausto perambula incessantemente por espaços exíguos, há uma necessidade de que a câmera esteja em constante movimentação para acompanhar os diálogos e as relações de interação entre o médico e os demais personagens. Essa necessidade obriga Sokurov a usar uma steadicam ${ }^{10}$ em boa parte do filme e a dar preferência aos planos-sequência; isto é, rodando as cenas com poucos cortes. Esse procedimento, aliás, faz parte do repertório estilístico de Sokurov, que possui um filme inteiro realizado em um único plano-sequência: A arca russa (2002). Jeremi SZANIAVSKI definiu esses incessantes movimentos de câmera de Fausto, realizados com o uso da steadicam, através da metáfora "danse macabre", que seria resultante da

[...] uncanny sensation reinforced by this specific technology, but it is further dynamised, dialecticised by the film's relatively quick editing, reinforcing the idea of contrary motion when two camera movements going in different directions collide. The subsequent effect is one of a carefully crafted choreographic wonder, a danse macabre of light and shadow, wherein the latter always threatens to conquer the former ${ }^{11}$ (SZANIAWSKI 2014: 259).

\footnotetext{
${ }^{9}$ Fonte: http://becuo.com/isolda-dychauk-faust. Acesso em: 8 jan. 2015.

${ }^{10}$ Steadicam consiste em um mecanismo no qual uma câmera é acoplada ao corpo do cinegrafista e que permite que ele se movimente sem que haja trepidações na imagem, dando a impressão de que a câmera flutua em torno do espaço.

11 "sensação inquietante é reforçada por essa tecnologia específica, que se torna ainda mais dinâmica e dialética pela edição relativamente ágil do filme, reforçando a ideia de movimentação oposta quando dois movimentos de câmera em direções opostas vão colidir. O efeito subsequente é de uma cuidadosa
} 
Ao realizar um movimento incessante de busca angustiada pela realização dos desejos, Fausto vai, por uma certa ironia do destino, efetuando uma espécie de dança ritualística em direção à própria morte, que começa com o seu encontro com Mauricius Müller e continua com o cumprimento de várias outras etapas, como o pacto, a realização do desejo e a contrapartida; isto é, a entrega da própria alma ao agiota.

\subsection{Luz e cor}

Não é nenhuma surpresa que Rembrandt Harmenszoon van Rijn tivesse sido o pintor holandês mais admirado por Constantijn Huygens, preposto cultural do príncipe de Orange e amante dos jogos de ótica. Como observa Simon ScHAMA, "Nenhum dos seus contemporâneos se comparava a ele, quando se tratava de captar o reflexo da luz num peitoral de aço, o brilho de um brinco de pérola ou a trama de um jabô de renda" (SCHAMA 2010:135). Rembrandt criou uma pintura de luz; e, ao fazê-lo, construiu um espaço em profundidade, em que a iluminação se torna seletiva e confere peso emocional aos gestos e às cores. Rembrandt criou a luz atmosférica ${ }^{12}$.

Durante o período de preparações para a filmagem de Fausto, Aleksandr Sokurov convidou o fotógrafo Bruno Delbonnel para uma visita ao Museu do Hermitage, em São Petersburgo, onde eles ficaram um bom tempo admirando aquele sussurro de luz que Rembrandt parece lançar sobre suas figuras:

On est resteé deux heurees devant le portrait d'une femme âgée peint par Rembrandt. Il disait voir l'âge dans la touche. Il veut trouver au cinema cette qualité d'émotion dans la matière, la durée""13 (BÉGHIN 2012: 16).

Vejamos a pintura que motivou a longa contemplação de Aleksandr Sokurov e Bruno Delbonnel:

\footnotetext{
destreza coreográfica admirável, uma dança macabra de luz e sombras, na qual este último sempre ameaça pôr a forma em perigo" (tradução minha).

${ }^{12}$ De acordo com Jacques Aumont, "Os inícios pictóricos da luz atmosférica são antigos: a maioria dos Rembrandts". (AUMONT 2004: 175).

13 "Nós ficamos duas horas diante de um retrato de uma velha senhora pintada por Rembrandt. Ele dizia ver a idade dela pelo toque. Ele quer encontrar no cinema essa qualidade de emoção na matéria, na duração" (tradução minha).
} 
Martoni, A. - Stimmungen no Fausto de Sokurov

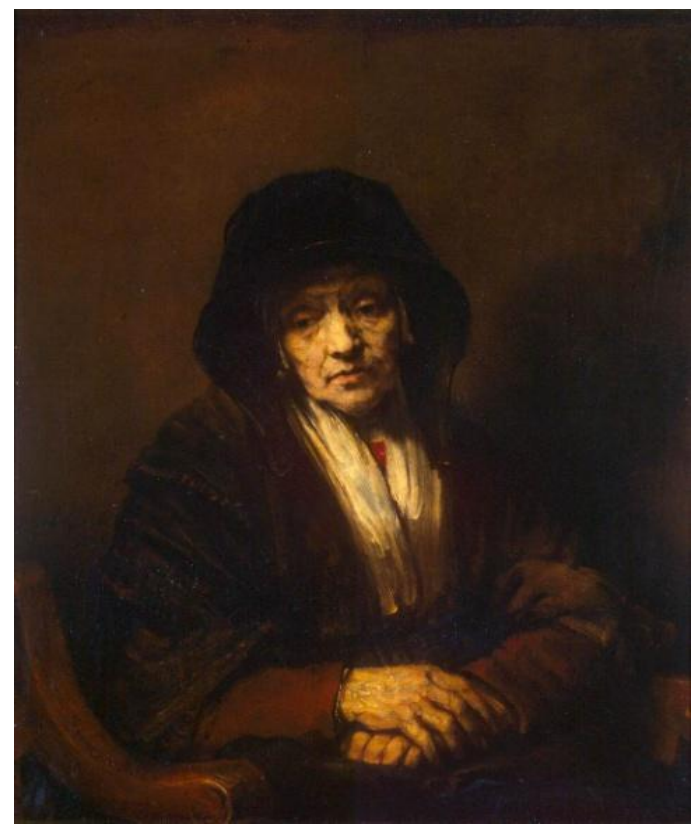

Figura 3: Rembrandt van Rijn, Retrato de uma velha senhora $(1654)^{14}$

A extrema acuidade de Aleksandr Sokurov com os aspectos plásticos da imagem rendeu-lhe a alcunha de "cineasta-pintor" 15 . Uma visada na filmografia do realizador russo só vem a confirmar essas afinidades eletivas entre o seu cinema e o domínio da pintura, seja buscando composições e distribuições de luz próprias a pintores como Rembrandt e Caspar David Friedrich, seja, de certa forma, prestando homenagem à própria história da pintura, através de filmes como A arca russa (2002), inteiramente rodado dentro do Museu do Hermitage, em São Petersburgo, e Elegia de uma viagem (2001), uma espécie de incursão afetiva pela história da pintura.

Evidentemente, o que justifica o fato de Aleksandr Sokurov reservar duas horas na contemplação de uma imagem como esta parece ser o desejo de compreender como, através do dispositivo técnico, seria possível criar uma atmosfera semelhante à da pintura de Rembrandt. O que está em jogo é um pacto com a técnica; pacto que lhe permitiria transportar a natureza plástica produzida por pigmentos coloridos sobre o suporte sólido para o domínio de uma película fotográfica sensível à luz. A alquimia de Sokurov visa à luz atmosférica, como se pode ver abaixo:

\footnotetext{
${ }^{14}$ Fonte: http://www.wga.hu/html_m/r/rembrand/24portral. Acesso em: 20 jan. 2014.

15 Segundo Álvaro MACHADO, o cinema de Sokurov apresenta "elementos de uma autêntica desconstrução do espaço narrativo pelo império da imagem, coisa que o caracteriza desde o início como 'cineasta-pintor"'. (MACHADO 2002: 18).
} 
Martoni, A. - Stimmungen no Fausto de Sokurov

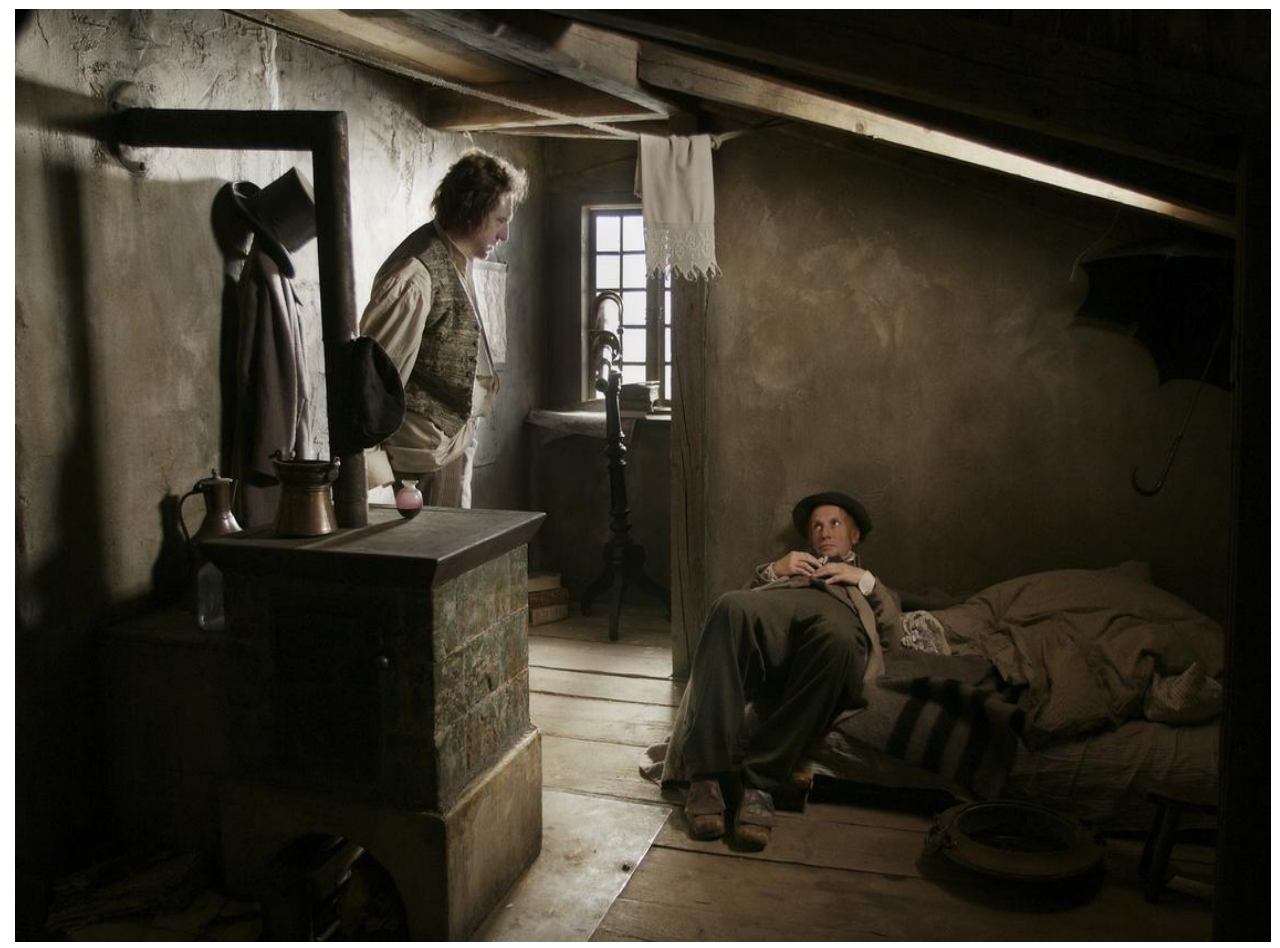

Figura 4: Fotograma do Fausto de Aleksandr Sokurov ${ }^{16}$.

No plano em destaque, que compõe uma das primeiras sequências do filme, Fausto recebe, em sua casa, a visita de Mefistófeles. Estamos diante de um plano aberto, em que a câmera, numa perspectiva diagonal, mostra o protagonista, em pé e de perfil, dirigindo seu olhar ao agiota, deitado no campo inferior da imagem. Há, aqui, duas fontes de luz visíveis no interior do plano: uma amarelada que emana de uma claraboia e ilumina a face de Mefistófeles, e outra que avança pela janela ao fundo, mais esbranquiçada. Apesar de a arquitetura, a mobília e o vestuário nos situarem, em termos de estilo, em um tempo distante, temos a impressão de que há, também, a reminiscência de um passado impressa na luz e na cor. Portanto, o desafio aqui se dá em fazer com que a iluminação do ambiente, a captação realizada pela câmera e o trabalho de coloração final consigam criar, através dos meios técnicos cinematográficos, um efeito próximo àquele obtido pelo pintor holandês através do pigmento sobre a superfície sólida. $\mathrm{O}$ esforço de Sokurov pode ser aproximado daquilo que Jacques AUMONT define da seguinte forma: "trabalhar a aparência plástica da imagem é sempre procurar modelar o material fotográfico para torcê-lo "no sentido do sentido"” (AUMONT 2004: 171). E o sentido buscado pelo realizador russo é aquele que sugira ao espectador uma experiência de imersão em um tempo passado a partir do modo como a luz se distribui

\footnotetext{
${ }^{16}$ Fonte: www.dicta.com.br. Acesso em: 22 jan. 2015.
} 
no plano: estamos num outro tempo, em que as cores chumbo/estanho/amarelo são provenientes da própria tonalidade emitida pelas fontes de luz existentes: a vela, a lamparina e o sol. Um amarelo, a propósito, como o das telas de Rembrandt, que, segundo Simon SCHAMA, "arde perigosamente, fosforicamente. É uma luz que pode chamuscar quem não se afasta" (SCHAMA 2010: 136).

Essa abordagem claramente pictórica da composição, da luz e da cor, em Sokurov, impõe, ao material fílmico, efeitos análogos ao pigmento, à massa de tinta ainda que tenham natureza qualitativa distinta - e, desse modo, somos remetidos a um tempo que não conhecemos através da fotografia ou do cinema, uma vez que os dispositivos que os tornam possíveis nem existiam, mas através das pinturas renascentista, barroca e romântica - para ficarmos nas concepções plásticas mais evidentes em Fausto. Esse trabalho de criação de uma luz atmosférica é diretamente responsável por um dos aspectos mais estonteantes do filme de Sokurov: as cores, como os fotogramas a seguir revelam:

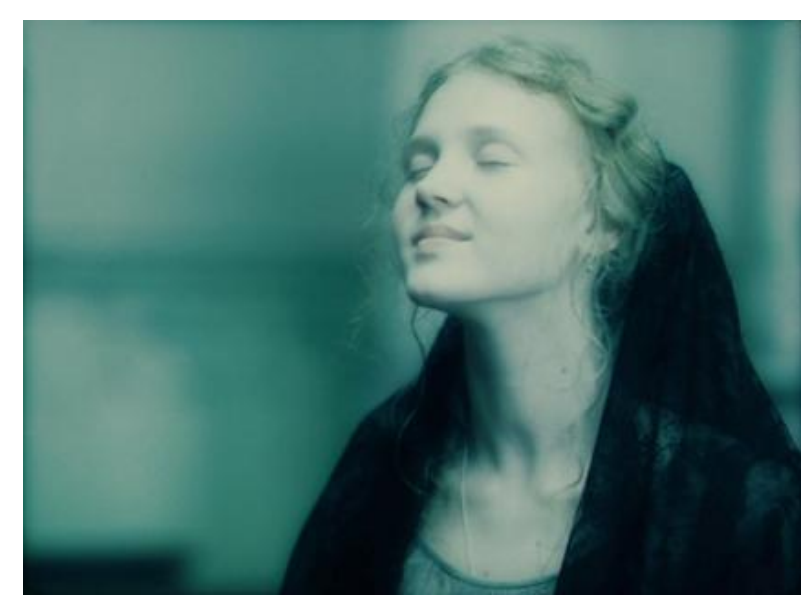

Figura 5: Fotograma mostra Margarida no interior de uma catedral ${ }^{17}$.

\footnotetext{
${ }^{17}$ Fonte: http://corrierino.com/forum/viewtopic.php?p=925369. Acesso em 15 jan. 2014.
} 


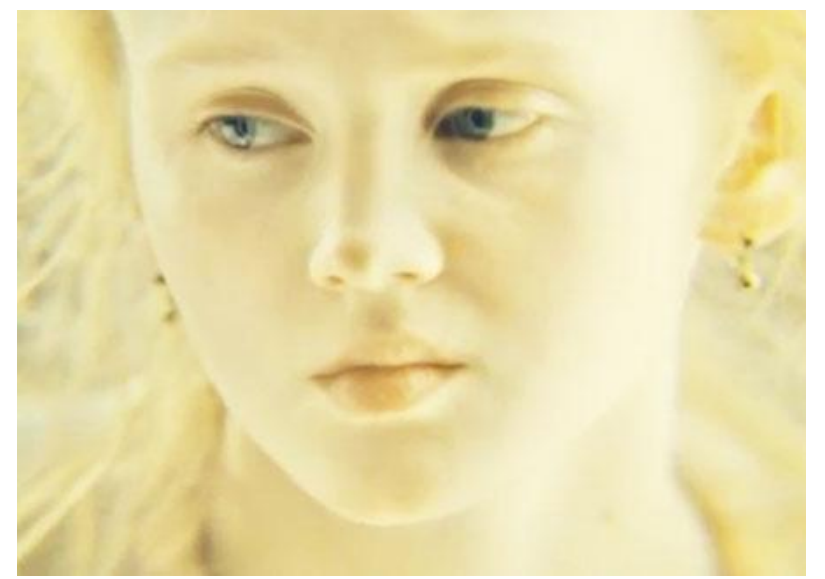

Figura 6: Fotograma mostra Margarida durante a relação sexual com Fausto ${ }^{18}$.

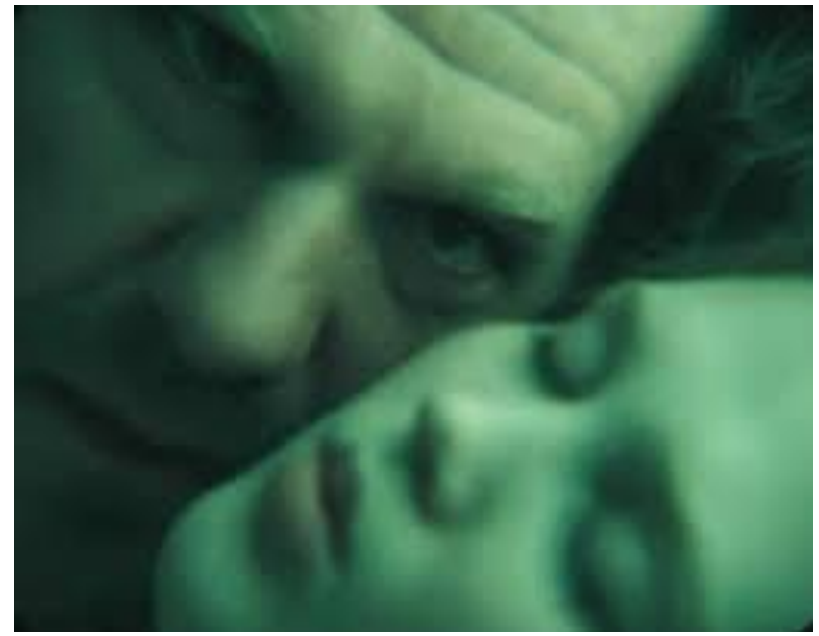

Figura 7: Fotograma apresenta Fausto e Margarida durante a relação sexual ${ }^{19}$.

Os três fotogramas em destaque nos permitem perceber que, ainda que o filme de Sokurov possua uma unidade plástica, a textura da imagem e os padrões de marcação de cor oscilam bastante ao longo de sua exibição. É visível como há, nos três casos, uma tendência ao monocromatismo - azul, amarelo-dourado e verde-azulado, respectivamente. Há também, entre os três, notáveis diferenças de contrastes: forte, no primeiro e terceiro fotogramas, e tênue, no intermediário. Ao fim e ao cabo, essas variações abruptas de sistemas cromáticos, de um plano para outro, parecem ser,

\footnotetext{
${ }^{18}$ Fonte: http://www.jblog.com.br/leiacinema.php?itemid=30281. Acesso em 15 jan. 2014.

${ }^{19}$ Fonte: tswjournal.wordpress.com. Acesso em 15 jan. 2014.
} 
também, em grande medida, responsáveis pela atmosfera alucinante e atordoante do filme.

O método de étalonnage $e^{20}$ do filme de Sokurov revela o trabalho meticuloso do realizador em pensar a atmosfera própria de cada cena, de cada plano, como se um único fotograma fosse uma tela, com composição e relações cromáticas próprias. A pintura compõe, a propósito, o próprio método utilizado por Sokurov para chegar ao resultado final desejado, como a imagem a seguir revela (Fig. 8).

O storyboard em destaque nos permite compreender o método de trabalho do realizador russo no que diz respeito à étalonnage. À esquerda, encontramos a decupagem do filme quadro a quadro, enquanto, à direita, é possível ver as indicações de cores buscadas por Sokurov através do uso de tinta guache ou lápis de cera. A observação desse trabalho revela um esforço de Sokurov de atingir o pictural tanto no processo de pré-produção, como no de pós-produção. Aqui, também, é possível e estimulante pensar, mais uma vez, sobre o esforço do realizador em fazer a matéria fílmica apresentar características análogas à matéria pictórica; em outras palavras, em fazer com que o aparato técnico possa gerar imagens cujos aspectos plásticos sugiram formas trabalhadas à mão. Para Beatriz Furtado, é justamente essa "vontade de pintura, como princípio plástico e força criadora, que imprime na imagem um plano de composição, figuras de pensamento e blocos de sensações” (FURTADO 2013: 16).

\footnotetext{
${ }^{20}$ A étalonnage - em português, "marcação de luz e correção de cor" - é um procedimento técnico realizado após a montagem final do filme e que tem como objetivo fazer com que as cores e os contrastes das diferentes cenas filmadas em diferentes ambientes e com diferentes luzes sejam igualadas para que $o$ espectador tenha uma percepção homogênea em termos de textura de imagem.
} 
Martoni, A. - Stimmungen no Fausto de Sokurov

\section{É V É N E M E N T}
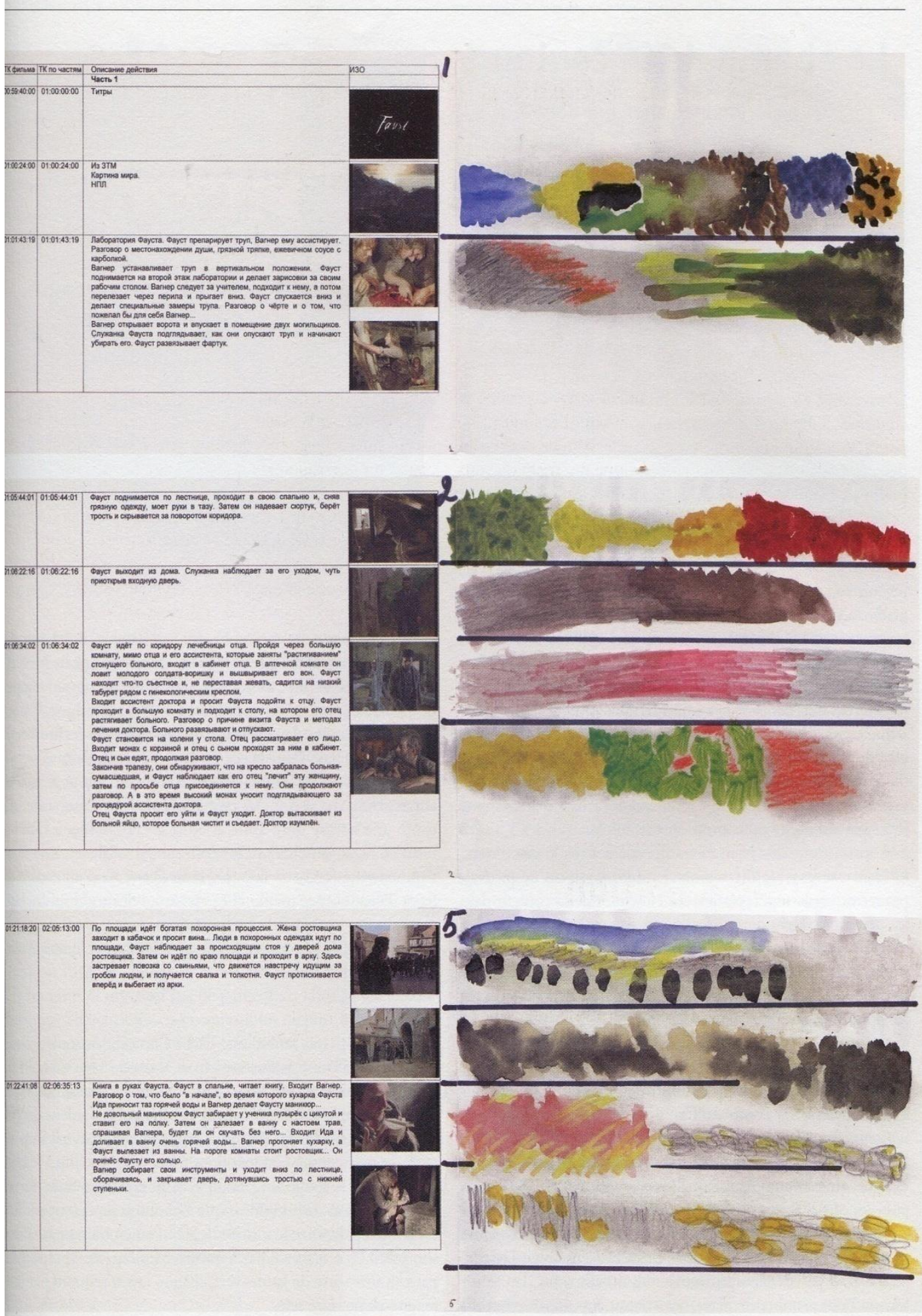

Figura 8: Storyboard com intervenções de Sokurov com tinta e lápis de cera ${ }^{21}$.

${ }^{21}$ Cahiers du Cinéma. N. 679. Junho/2012. p.15. 
O trabalho de Aleksandr Sokurov com as cores revela que o diálogo do diretor russo com Goethe não se limita à poesia dramática do escritor alemão, que serviu de base para sua adaptação cinematográfica, mas abarca, também, as incursões de Goethe no campo das ciências naturais, particularmente os apontamentos feitos na obra Doutrina das cores (Farbenlehre). Ao ser questionado sobre em que medida essa obra influiu sobre o tratamento dado às cores no seu Fausto, Sokurov assevera que tal influência ocorreu “Sans aucune doute. C'est l'un des traités esthétiques fondamentaux qui possède, à mes yeux, une grande valeur pratique. Surtout pour moi"22 (BÉGHIN 2012: 14).

Publicada em 1810, esta obra se notabilizou como uma relevante incursão do escritor alemão no domínio das ciências naturais. O livro era resultado de um trabalho que havia começado anos antes, quando em 1791, após uma viagem à Itália, Goethe inicia uma série de experimentos com lentes e prismas que, em última instância, buscava questionar as ideias de Isaac Newton acerca da teoria cromática. Contudo, é provável que a última seção do livro - "Efeito sensível-moral da cor" - tenha influído de forma mais decisiva no trabalho cromático de Sokurov em Fausto. Nesta seção, Goethe busca investigar as interações entre percepção e conhecimento, na medida em que, segundo o escritor alemão, "A experiência nos ensina que cores distintas proporcionam estados de ânimo específicos” (GOETHE 2011: 139); isto é, a cor “estimula em nosso olho a sensação de sua qualidade" (2011: 146).

O trabalho de Sokurov parece, ainda que de um modo não esquemático, tentar explorar o potencial das cores de criar modulações afetivas às cenas. Voltando aos três fotogramas apresentados juntos página 17, é possível perceber mais claramente essa relação. No primeiro fotograma, a tonalidade azul que envolve o rosto de prazer de Margarida dentro da igreja parece reforçar o caráter celestial, de pureza que envolve a personagem. No segundo, o amarelo-ouro parece estimular o nosso olhar a percorrer o rosto da personagem. É relevante lembrar que Goethe definiu que o amarelo possui uma “impressão calorosa e agradável” (GOETHE 2011: 141). Já no terceiro, o olhar lascivo de Fausto, ao se aproximar de Marguerite enquanto ela dorme, desejando violentá-la, se encontra envolto em uma tonalidade monocromática verde, o que reforça, de alguma forma, um certo desconforto moral do espectador com a cena, ratificando o modo como Goethe pensou o efeito sensível-moral desse tom: "a cor de enxofre, que tende ao verde,

\footnotetext{
22 "Sem nenhuma dúvida. É um dos tratados estéticos fundamentais que possui, a meu ver, um grande valor prático. Sobretudo para mim" (tradução minha).
} 
Martoni, A. - Stimmungen no Fausto de Sokurov

tem algo de desagradável" (GoETHE 2011: 141). Portanto, ainda que não se possa exatamente pensar em uma gramática das cores entre sensação e moral, como pensou Goethe, essa ideia parece ser bem produtiva para se compreender o trabalho de Sokurov com elas; um trabalho que parece ser pautado pela construção de ambiências a partir da busca de afinidades entre as sensações visuais e a construção das Stimmungen.

\subsection{Deformação}

Giambattista della Porta viveu em um período muito próximo a Georg Faustus. E assim como o médico alemão, o físico italiano nutria interesse pelo mundo da magia, o que o levou, a propósito, a ser acusado pelo papa Paulo V de praticar nigromancia. Em Magiae naturalis, livro impresso em Nápoles em 1558, della Porta descrevia uma experiência ótica fascinante, a existência de "espelhos que alongavam ou encurtavam os rostos, tornavam os homens mais velhos ou mais jovens, deformavam-nos e desfiguravam-nos" (MANNONI 2003: 45).

Pouco mais de duzentos anos depois, é apresentado, em Paris, o primeiro espetáculo de Fantasmagoria, projeções que se utilizavam da mesma lanterna mágica que Goethe vislumbrava empregar na encenação do seu Fausto. Desse modo, as experiências óticas com anamorfose se tornaram uma forma de entretenimento popular, como nos lembra Jurgis BALTRUSAITIS: "O sistema foi estabelecido inicialmente como uma curiosidade técnica, mas abrangeu também uma poética da abstração, um efetivo mecanismo de produção de ilusão de ótica" (apud MACHADO 1997: 59). Em seu estudo sobre a arqueologia do cinema, Laurent Mannoni nos conta que, nesses primeiros espetáculos de Fantasmagoria, realizados por Étienne-Garpard Robert, no Convento dos Capuchinhos, em Paris, os espectadores, para chegarem à sala de exibição, eram obrigados a passar por um longo corredor onde havia uma série de pinturas fantásticas, entre as quais, "uma anamorfose intitulada 'Monstro encontrado no coração de uma bela mulher" e "um espelho cilíndrico que alongava a figura do espectador" (MANNONI 2003: 172).

O poder atordoante da visão agenciada pelas lentes anamórficas levou Aleksandr Sokurov a adotá-las em Fausto. De acordo com o realizador russo, em depoimento a Jeremi SZANIAWSKI, "we used a unique lens - a very large one (he gestures to about the size of a large tv screen). It creates inverted perspective. It is very difficult to operate, 
Martoni, A. - Stimmungen no Fausto de Sokurov

and there is only one model of it in the world"23 (SZANIAWSKI 2014: 304). A adoção das lentes anamórficas provoca, invariavelmente, uma perturbação na forma, como se pode perceber na reprodução dos fotogramas a seguir:

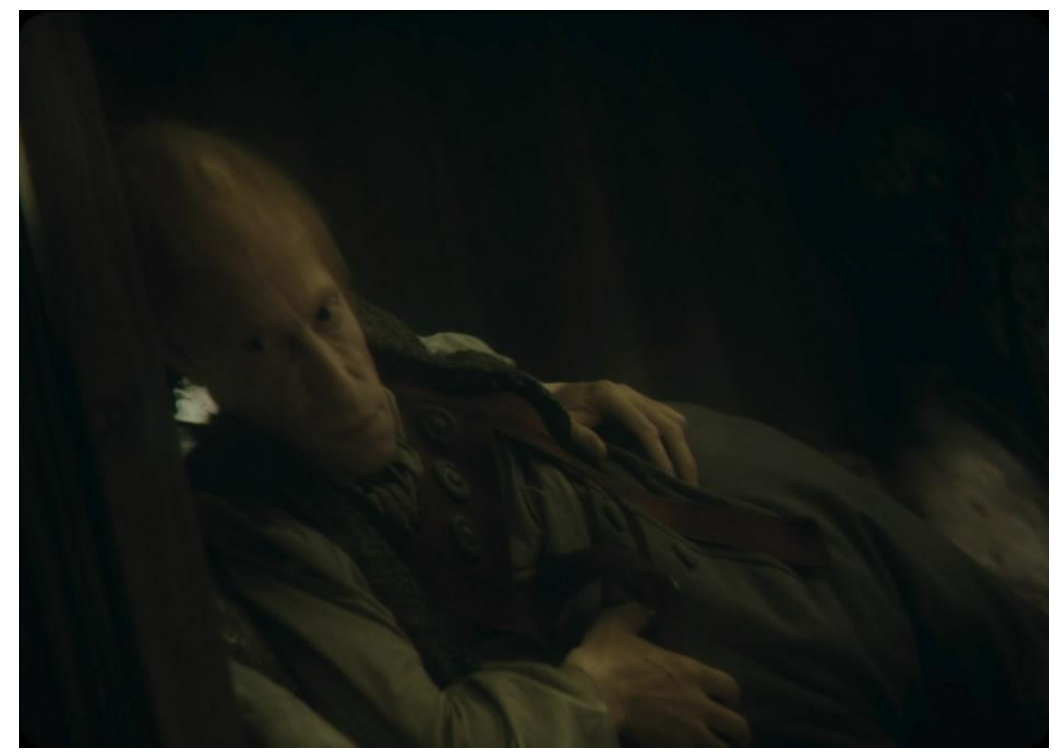

Figura 9: Fotograma mostra Mauricius Müller sob efeito das lentes anamórficas ${ }^{24}$.

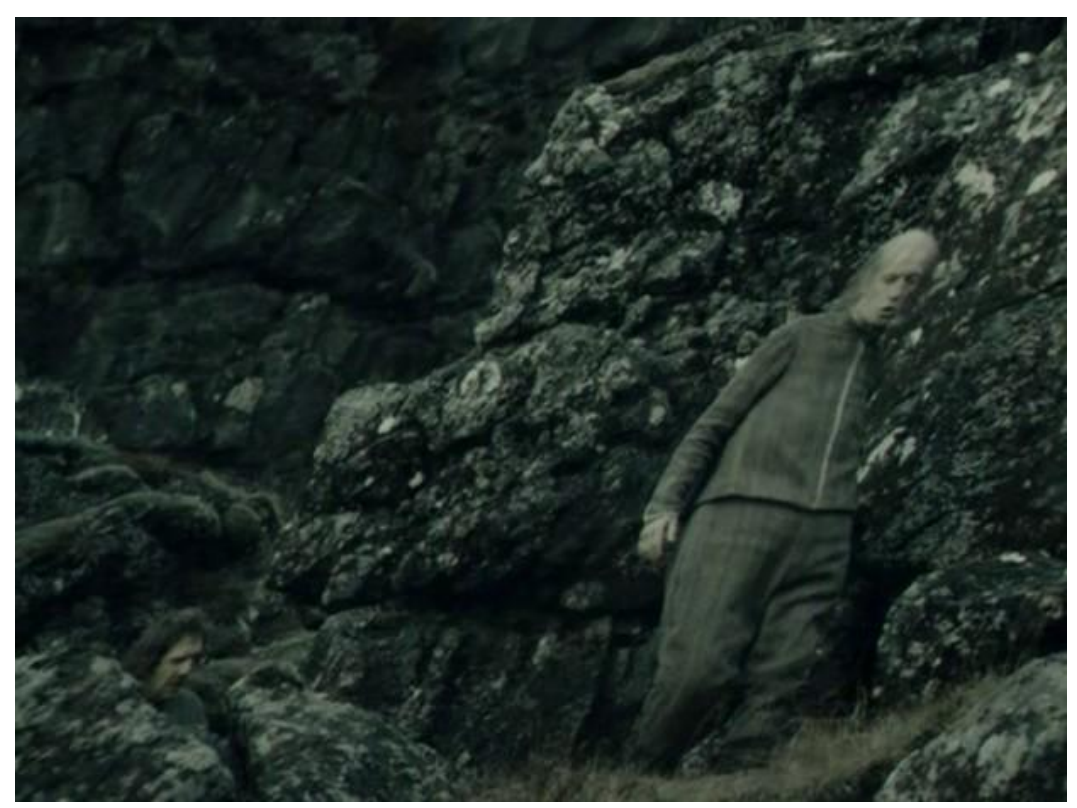

Figura 10: Fotograma mostra Mauricius Müller sob efeito das lentes anamórficas ${ }^{25}$.

\footnotetext{
23 "Nós usamos uma lente única - bem larga (ele mostra o tamanho aproximado de uma TV de tela plana. Ela cria uma perspectiva invertida. Ela é muito difícil de operar e só há um modelo no mundo" (tradução minha).

Fonte: http://moviessansfrontiers.blogspot.com.br/2012/05/128-russian-director-alexandersokurovs.html. Acesso em 10 fev. 2015.

25 Fonte: http://kinomusorka.ru/en/directors-director-alexander-sokurov-films-film-faust-2011.html. Acesso em 12 jan. 2014.
} 
Martoni, A. - Stimmungen no Fausto de Sokurov

A torção da matéria em direção à figura pode ser considerada um aspecto inerente à própria atividade artística. $\mathrm{O}$ escultor torce o mármore para extrair dele uma forma; o músico tensiona as cordas do violão para produzir o som; Sokurov manda construir lentes anamórficas para conferir à imagem um poder de expressão.

Ao observarmos os dois fotogramas em destaque, percebemos que as imagens se encontram tensionadas no sentido diagonal, fenômeno que causa uma ruptura tanto com o tipo de visualidade com a qual estamos habituados em nosso dia a dia, quanto com a própria natureza plástica oferecida pela maior parte do filme. É dentro dessa perspectiva que a contemplação desses fotogramas acaba por revelar como a imagem passa a ser muito mais do que uma representação de algo para se tornar uma testemunha do modo como o tratamento dado ao material fotográfico torna a própria materialidade visível; resultado da ação de um sistema de forças sobre ela. Gilles Deleuze se perguntava, acerca da pintura de Francis Bacon, sobre como ela tornava visíveis forças invisíveis; como as cabeças agitadas do artista inglês apresentavam um movimento que era resultado de "forças de pressão, dilatação, contração, achatamento, estiramento que se exercem sobre a cabeça imóvel” (DELEuzE 2007: 64). De forma análoga, a distorção, uma vez que não se localiza em um ponto específico da imagem, como nas cabeças pintadas por Bacon, mas em toda sua extensão, torna visível a ação de um fenômeno ótico, de uma força; neste caso, de uma concavidade e espessura das objetivas que desviam a luz que atravessa a lente, deslocando o centro ótico da imagem.

A existência de um sistema de forças que age sobre a imagem nos permite refletir sobre as ideias de atmosfera, clima e ambiência em uma outra perspectiva. Na clave romântica, como é sabido, esses termos estavam intrinsecamente ligados a ação de fenômenos meteorológicos sobre a paisagem - o vento que agita a copa das árvores, por exemplo -, ou a existência de forças desconhecidas que atuam sobre a realidade - um caixão de se abre sozinho, por exemplo. No caso dos fotogramas em destaque, as forças que atuam sobre a realidade visível, no filme, decorrem de uma ação da própria técnica; é ela a responsável pela revelação desses fenômenos óticos que atuam sobre o nosso modo de ver, criando uma atmosfera singular. É sintomático, nesse sentido, que Rudolf KURTZ (2007) defina o expressionismo como um modo de evocar aquilo que não é fotografável; e este algo não fotografável nos parece ser o próprio tempo, se pensarmos na proposta de Arlindo MACHADO de entender a anamorfose como uma forma de sua inscrição na imagem: “o tempo surge então como um elemento transformador, capaz de 
abalar a própria estrutura da matéria, de comprimi-la, dilatá-la, multiplicá-la, torcê-la até o limite da transfiguração" (MACHADO 1997: 70).

Ainda que não tenha, convencionalmente, uma função narrativa dentro do filme, o emprego desses efeitos acaba por induzir o próprio espectador a tentar encontrar um porquê para tal procedimento estético; isto é, uma relação de pertinência entre forma e conteúdo. Curiosamente - ou não -, o uso das lentes anamórficas ocorre em momentos em que se suspeita da presença de forças sobrenaturais: no caso do primeiro fotograma, o encontro inicial de Fausto com Mauricius Müller (Mefistófeles); já no segundo, a condução de Fausto em direção ao inferno. Portanto, a presença de forças sobrenaturais é sugerida através do uso de forças óticas, matéria que atua sobre a nossa percepção. Em sua análise do quadro $O$ enterro do conde Orgaz, de El Greco, Deleuze sugere que o modo como as figuras da metade superior do quadro do pintor maneirista espanhol aparecem, afinando-se desmesuradamente, se daria em função daqueles corpos estarem expostos a "sensações celestes, infernais ou terrestres" (DELEUZE 2007: 18). Em Fausto, as distorções na plástica da imagem atestam, mais uma vez pensando com DELEUZE, que "as Figuras divinas [ou demoníacas, acrescentamos] são animadas por um livre trabalho criador, por uma fantasia que se permite qualquer coisa" (2007: 18).

\section{Considerações Finais}

Nossa questão de partida, neste trabalho, consistiu em compreender a importância da técnica na construção das atmosferas do Fausto de Aleksandr Sokurov. Neste sentido, a partir da análise empreendida, é possível concluir que os dispositivos técnicos desempenham um papel fundamental no processo de construção das Stimmungen, tendo em vista que, como ficou evidenciado, os aspectos da ordem da materialidade da linguagem - no caso, os meios de expressão da linguagem cinematográfica - influem sobre as disposições afetivas do espectador. Neste sentido, esta análise também revelou uma outra dimensão do diálogo de Sokurov com Goethe: aquela concernente às imbricações entre técnica e estética. Mais do que uma adaptação de um texto literário para o cinema, o Fausto de Sokurov é uma obra que busca traduzir, para a contemporaneidade, uma determinada forma de experiência sensível.

O filósofo argentino Hernán Ulm chamou a atenção para o fato de que "Não é possível [...] dizer que a matéria 'encarna' os significados. Cada materialidade produz um 
Martoni, A. - Stimmungen no Fausto de Sokurov

sentido que não se remete à encarnação" (2014: 27). Dentro dessa perspectiva, o Fausto de Sokurov não se apresenta como um filme que supostamente encarnaria um sentido emanado pela tragédia de Goethe, mas como uma obra resultante do próprio esforço do realizador russo em torcer o material fílmico a fim de extrair dele uma forma análoga de experiência sensível. Desse modo, de Goethe a Sokurov, os afetos na ordem da claustrofobia, da alucinação e do atordoamento irrompem no modo como, a fim de se traduzir ambiências, os dispositivos técnicos são empregados para a produção das Stimmungen; seja na forma de projeção de rostos em dimensões gigantescas, na construção de uma cortina de fumaça, no emprego da anamorfose, no monocromatismo, na luz atmosférica de Rembrandt, no uso da lanterna mágica; enfim, em todos aqueles momentos em que, buscando, de alguma forma, uma irremediável sensibilização do outro, o homem, de forma consciente e deliberada, buscou uma aliança com a técnica.

\section{Referências bibliográficas}

Aumont, Jacques. O olho interminável: cinema e pintura. São Paulo: Cosac Naify, 2004.

BÉGHIN, Cyril. Comment Faust passa la montagne. In: Cahiers du Cinéma n. 679. Paris, jun. 2012, 6 .

Aleksandr Sokurov, peintre de la couleur. In: Cahiers du Cinéma n. 679. Paris, jun. 2012, 14.

. Le champ de la couleur. In: Cahiers du Cinéma n. 679. Paris, jun. 2012, 16.

Benjamin, Walter. Ensaios reunidos: escritos sobre Goethe. São Paulo: Duas Cidades; Ed. 34, 2009.

Berman, Marshall. Tudo que é sólido desmancha no ar. São Paulo: Companhia das Letras, 2007.

BORDWELL, David; THOMPSON, Kristin. Film art: an introduction. Wisconsin: University of Wisconsin, 2009.

BUCK-MORSS, Susan. "Estética e anestética: uma reconsideração de A obra de arte de Walter Benjamin”. In_BENJAMIN, Walter [et al.], Benjamin e a obra de arte: técnica, imagem e representação. Rio de Janeiro: Contraponto, 2012.

DeleuZE, Gilles. A imagem-movimento. Lisboa: Assírio \& Alvim, 1983.

. Francis Bacon: Lógica da sensação. Rio de Janeiro: Jorge Zahar Ed., 2007.

DesCARTES, René. Meditações metafísicas. São Paulo: Martins Fontes, 2011.

EISNER, Lotte. A tela demoníaca: as influências de Max Reinhardt e do expressionismo. São Paulo: Paz e Terra, 2002.

EPSTEIN, Jean. "Realização do detalhe". In: XAVIER, Ismail (Org.). A experiência do cinema. Rio de Janeiro: Edições Graal: Embrafilme, 1983.

FurTADO, Beatriz. "A imagem-intensidade no cinema de Sokurov". In: PARENTE, André. Cinema/Deleuze. Campinas, SP: Papirus, 2013.

GOETHE, J.W. von. Os sofrimentos do jovem Werther. [tradução: Marion Fleischer]. São Paulo: Martins Fontes, 2000. 
Martoni, A. - Stimmungen no Fausto de Sokurov

. Doutrina das cores. [tradução: Marco Giannotti]. São Paulo: Nova Alexandria, 2011. . Fausto: uma tragédia. [tradução: Jenny Klabin Segall]. São Paulo: Ed. 34, 2004.

GuMBreCHT, Hans Ulrich. Atmosfera, ambiência, Stimmung. Rio de Janeiro: Contaponto, PUC, 2014.

KURTZ, Rudolf. Expressionismus und film. Berlin: Chronos Verlag, 2007.

MACHADO, Álvaro. "O planeta Sokúrov”. In_Aleksandr Sokúrov. São Paulo: Cosac \& Naify, 2002.

Machado, Arlindo. Pré-cinemas e pós-cinemas. Campinas, SP: Papirus, 1997.

. O sujeito na tela: modos de enunciação no cinema e no ciberespaço. São Paulo: Paulus, 2007.

MAHL, Bernd. Goethes Faust auf der Bühne. Stuttgart; Weimar: Verlag J.B. Metzler, 1998.

MANNONI, Laurent. A grande arte da luz e da sombra: arqueologia do cinema. São Paulo: Editora SENAC São Paulo: UNESP, 2003.

Rose, Steven. Aleksandr Sokurov: desilusions and grandeur. The Guardian. London, nov. 2011. http://www.theguardian.com/film/2011/nov/14/aleksandr-sokurov-faust. (15/01/2014).

SCHAMA, Simon. O poder da arte. São Paulo: Companhia das Letras, 2010.

SCHÖNE, Albrecht. Faust. Texte und Kommentare (Deutscher Klassiker Verlag). Frankfurt, 2005.

ScotT, A. O. The muse of Goethe intensified. In: The New York Times. New York, nov. 2013. http://www.nytimes.com/2013/11/15/movies/faust-is-last-film-in-alexander-sokurovsmen-of-power.html?_r=0. (15/01/2014).

SPITZER, Leo. "Milieu and ambience". In_Essays in historical semantics. New York: Russel \& Russel, 1968.

. Ideas clásica y Cristiana de la armonía del mundo. Madrid: Abada Editores, 2008.

SZANIAWSKI, Jeremi. The cinema of Aleksandr Sokurov: figures of paradox. New York: Wallflower Press Books; Columbia University Press, 2014.

ULM, Hernán. A fenda incomensurável: Literatura e cinema. Tese de Doutorado. Niterói: Universidade Federal Fluminense, 2014.

WATT, Ian. Mitos do individualismo moderno. Rio de Janeiro: Jorge Zahar Ed., 1997.

WELLBERY, David. "Stimmung". Historisches Wörterburch äestheticher Grundbegriffe, v.5: Postmoderne - Synästhesie. Ed. Karlheinz Barck et al. Stuttgart / Weimar: Metzler, 2003.

Recebido em 11/08/2015

Aceito em 10/09/2015 